\title{
NESTING COMMON RAVENS NEAR BREDENBURY EAT SALAMANDERS
}

\author{
KORT LARSEN, Box 479, Saltcoats SK SOA 3R0
}

The Common Raven is a recentlyestablished summer resident in our area around Saltcoats in eastern Saskatchewan, although it was more common than the American Crow on the plains 150 years ago. ${ }^{2}$ After about a century of absence, apart from a winter straggler every ten or twenty years, ravens became regular winter visitors near Saltcoats about 1983, and became rare summer residents starting in the late 1980s. Bill Horseman reports that, in our area, ravens now nest deeply in the centre of most aspen stands of greater than 40 acres (16 ha), unlike their relative, the American Crow, which nests closer to the edge and more than a month later. Bill found a raven's nest north of Bredenbury $(40 \mathrm{~km} \mathrm{SE}$ of Yorkton) in 1999 wherein 4 of 6 eggs hatched on 12 April 1999.

I wish to report an unusual food item eaten by ravens. On two occasions, I observed ravens feeding salamanders to their young. On the first occasion, in the last week of June 1995, when I was cutting green oat feed with Fred Moore, a mile east and 3.5 miles north of Bredenbury, a pair of ravens was feeding a large salamander to its young.

On the second occasion, about 20 June 1997, a full-sized raven was sitting on the road beside a large slough, about six miles west of Bredenbury. At first, I thought it to be an adult, but it soon proved to be a young raven still being fed by its parent. No doubt it had been raised in a nest nearby, and had only recently learned to fly. As I stopped to watch, an adult raven flew in from a nearby slough, bringing its hungry young bird a large salamander, which was accepted eagerly. What a mouthful! The large, dark, rubbery salamander was held sideways in the young raven's mouth. I watched the bird's vain attempts to swallow it for ten minutes. Finally, the young raven managed to turn the large salamander lengthwise, and then, but still with difficulty, to swallow it.

These salamanders were 18 to $20 \mathrm{~cm}$ in length and had prominent collars composed of gills "like miniature ostrich plumes." It is most likely that these salamanders were larval forms of the Tiger Salamander (Ambystoma tigrinum) or possibly neotenic adults of this same species which become sexually mature without changing to the gill-free adult form. A much less likely possibility is that the salamanders were Mudpuppies (Necturus maculosus). This species has not been reported in Saskatchewan, but it occurs in Manitoba in the Assiniboine River drainage near the Saskatchewan border.

As with other members of the crow and jay family, the Corvidae, ravens are omnivorous, eating almost anything. A study from Oregon in 1934 showed that rabbits were the main summer diet, but insects formed $30 \%$, nestling birds $6 \%$, and amphibians (mainly frogs), $7 \%{ }^{3}$ 


\section{Acknowledgments}

I wish to thank Martin Gerard for his encouragement, Andy Didiuk for comments on the species of salamander present in our area, and Stuart Houston for assistance in preparing this report.

1. Conant, R. 1958. A Field Guide to Reptiles and Amphibians. Houghton Mifflin, Boston.
2. Houston, C.S. 1977. Changing patterns of Corvidae on the prairies. Blue Jay 35:149-1563.

3. Nelson, A.L. 1934. Some early summer food preferences of the American Raven in southeastern Oregon. Condor 36:10-15.

\section{THE WESTWARD SPREAD OF THE BARRED OWL}

C. STUART HOUSTON, 863 University Drive, Saskatoon SK S7N 0J8, and KEVIN J. McGOWAN, Department of Ecology and Evolutionary Biology, Corson Hall, Cornell University, Ithaca NY 14853-2701.

Only during this century did the Barred Owl spread westward from Manitoba. Except for a widely-cited specimen from Calgary in 1912, now known to be an error, all other evidence has pointed to this owl being a new arrival. The alternative possibility, based on the Calgary specimen, was that the Barred Owl might have been present earlier in Saskatchewan and Alberta, but so rare and with so few observers, that it was overlooked. We argue that it is a new arrival, certainly in Alberta, British Columbia, and the northwestern states, and perhaps in Saskatchewan as well. Either it was overlooked in Saskatchewan for some years or its thin colonization of Saskatchewan and Alberta was nearly simultaneous.

In the eastern United States, west to the Red River valley on the western margin of Minnesota, Barred Owls are resident primarily in oak forests, but also in old-growth stands of maple and hemlock. Large, old trees offer suitable cavities for their nesting. ${ }^{10}$

It appears that Barred Owls followed the wooded Red and Assiniboine river valleys in their first incursion into Manitoba. Until the late 1880s, Barred Owls were considered "rare" at Winnipeg and adjacent southeastern Manitoba (three records) and "very rare, one specimen" slightly farther west at Portage la Prairie. ${ }^{21}$ Later at Winnipeg, there was a sight record for 1901, four specimens were taken in 1906 and one in 1908. ${ }^{16}$ A second specimen from Portage la Prairie was taken in May 1899. ${ }^{16}$ The range was extended westward when a specimen was taken in old-growth forest at Riding Mountain in January 1905. ${ }^{16}$ Taverner (1936) was unequivocal as to its 